Research Article

\title{
Statistical Analysis of Turkish Speaking Students' Phubbing Behaviors
}

\author{
Burcu TOKER 1 (D) Nazime TUNCAY *2 (D) \\ ${ }^{1}$ Bahçeşehir Cyprus University, Cyprus, burcu.toker@cyprus.bau.edu.tr \\ ${ }^{2}$ Bahçeşehir Cyprus University, Cyprus, nazime.tuncay@gmail.com \\ * Corresponding Author: nazime.tuncay@gmail.com
}

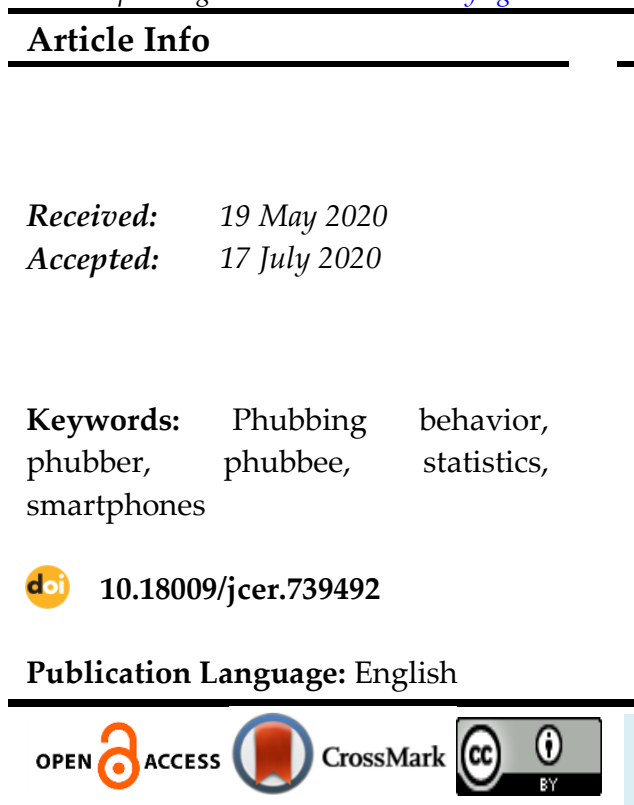

\begin{abstract}
As spending considerable time on Smart Phones has nearly become a norm, people ignoring other people around them in social environments, increased remarkably over the past decade. People being exposed to phubbing behaviors by their companions, looking at their phones repeatedly in social settings are feeling ignored. In this study, after an extensive literature review, data were collected from 352 participants via SurveyMonkey software regarding their perceptions about phubbing and being phubbed. The aim of this study is to find differences between Turkish Speaking Students' Phubbing Behaviors according to education, job status, working status and gender. Statistical analysis showed that, all participants stated "they get rid of their stress by interacting with their phones", though they do not mean to irritate others by focusing on their phones. Results also revealed that, Working participants are phubbed more compared to the Not Working and Retired participants.
\end{abstract}

To cite this article: Toker,B., \& Tuncay, N. (2020). Statistical analysis of turkish speaking students' phubbing behaviors. Journal of Computer and Education Research, 8 (16), 526-544. DOI: 10.18009/jcer.739492

\section{Introduction}

In the recent years, increased dependency on smartphones resulted in people engaging with their smartphones even while having a face-to-face conversation with others; a behavior commonly known in the literature as phubbing (Coehoorn, 2014). The person engaging with a smartphone instead of paying attention to another person or persons during a social interaction is called a "phubber," while the person who is being phubbed, that is, phone snubbed, during the social interaction is called the "phubbee" (Chotpitayasunondh \& Douglas, 2016). Mostly the number of hours in a day when we have virtual communication via our Smartphones is more than the number of hours when we have face to face chats.

Phubbing occurs at the conjunction of addictive focuses and has entered daily life as a multidimensional phenomenon severely affecting daily communication (Barrios-Borjas, 
Bejar-Ramos, \& CauchosMora, 2017). Students are constantly interrupted by non-relevant applications on their phones, indicating that the student users do not have sufficient control over their smartphone use and study habits (Chen,etc., 2019)

Smartphones in the last 15 years (Pendergrass \& Town, 2017), many addictive focuses like SMS addiction (Hassanzadeh \& Rezaei, 2011), Internet addiction (Tao et al., 2010; Weinstein \& Lejoyeux, 2010), and game addiction. Conscientious individuals can postpone their desires (Sleem \& El-Sayed, 2011) and manage their time as they wish (Živc ${ }^{`} i^{\prime}$ Bec'irevic', Smojver-Az ic' $^{\prime}$ \& \& Dorc $` i c^{\prime}$, 2017). Neurotic individuals are prone to depression (Shi, Liu, Yang, \& Wang, 2015) and a tendency to remain alone (Stokes, 1985). Research has similarly shown that phubbing has a positive correlation with depression (Wang et al., 2017) and loneliness (David \& Roberts, 2017). Kircaburun and Griffiths (2018) found that Instagram addiction is negatively related to conscientiousness and agreeableness.

Research has reported that the self-esteem of both neurotics (Marshall, Lefringhausen, \& Ferenczi, 2015; Scheier, Carver, \& Bridges, 1994) and individuals displaying phubbing behavior (Błachnio \& Przepiorka, 2018) is low (Charlton \& Danforth, 2010; Wood, 2008) have been collected into a single object.

Studies have shown that phubbing behavior negatively affected satisfaction and fulfillment obtained from the relationship between partners (Chotpitayasunondh \& Douglas, 2018; Gonza'lezRivera, Segura-Abreu, \& Urbistondo-Rodri'guez, 2018). Another negative effect of phubbing is reported in work life. Employees who stated that bosses paid attention to their phones during communication said they felt the work they did is not valued and selfconfidence about efficacy related to work reduced (David \& Roberts, 2017). It is understood from studies that there are negative reflections of phubbing in educational life just as in family and work life.

Emotional support from social media is positively related to college students' phubbing behavior ( Fanga,et.al, 2020). What is more, fear of missing out and problematic social media use could sequentially mediate the relationship between emotional support from social media and college students' phubbing behavior (Ozer, 2020; Fanga,et.al, 2020). Other findings obtaining similar results revealed that phubbing is commonly observed and is a responsible behavior from the student perspective (Ugur \& Koc, 2015). 
There are presence and usage of a system that warns phubber individuals walking in the street while looking at their phones that they have entered a dangerous area in terms of traffic (Du, Xing, and Gong, 2017). Metsiritrakul, Puntavachirapan, Kobchaisawat, Leelhapantu, \& Chalidabhongse (2016) transferred computer applications encouraging those who stopped phubbing and entered two-way communication via monitors placed in open public areas into the experimental results.

Wang, Xie, Wang, Wang, and Lei (2017) examined outcomes of phubbing and determined that phubbing may be related to depression and reduced fulfillment in relationships. Roberts and David (2016) identified that partners with anxious attachment style displayed more confrontational reactions when exposed to phubbing. Chasombat (2015) identified that those displaying phubbing behavior had reduced listening skills. Research carried out by Göksu \& Bolat (2020) stated that there is no significant difference in the effect of technology on academic achievement in terms of field/course and technologybased learning environments based on learning theories. The most careful observers and most addopted ones of technology are students (Tuncay, 2016). Students provide us valuable information about technology addiction, game addiction and phubbig behaviours.

The trend of phubbing among Turkish users is high (Erzen, Odaci,\& Yeniceri, 2019). They found that there is no significant relationship between the factors such as responsibility, extraversion, and agreeableness, but it is stated that there is a need for further research in order to determine which personality traits influence phubbing. Before proceeding to the method part, hypothesis based on work should be indicated if there is an objective to investigate absolutely.

\section{Method}

\section{Problem and Research Design}

Ignoring and being ignored by others in favor of a smartphone is a common feature of everyday communication. As a result of detailed literature review it is seen that:

- Smartphones and SmartPhone Addicion has been interest of many reseachers (Pendergrass \& Town, 2017; Hassanzadeh \& Rezaei, 2011; Tao et al., 2010; Weinstein \& Lejoyeux, 2010; Sleem \& El-Sayed, 2011; Z`ivc`ic'-Bec'irevic', Smojver-Ažic', \& 
Dorčic', 2017; Shi, Liu, Yang, \& Wang, 2015; Stokes, 1985; Wang et al., 2017; David \& Roberts, 2017; Kircaburun \& Griffiths 2018).

- $\quad$ Students who are interested in their phones and ignoring others/ being ignored is $21^{\text {st }}$ century decade problem (Coehoorn, 2014; Barrios-Borjas, Bejar-Ramos, \& CauchosMora, 2017; Du, Xing, \& Gong, 2017; Chotpitayasunondh \& Douglas, 2016; Erzen, Odaci,\& Yeniceri, 2019).

- $\quad$ A study carried out with 'Health Services Vocational High School' students, revealed that, the average internet usage was found to be 5 hours daily among students. When students were asked to enumerate the internet sites they use, the result was: social media, news sites, movie and series sites, educational and informational content sites, play sites, e-mail, shopping sites, and sexual content sites in order of usage preference(Yakıncı et al., 2018)

- Game arcades that have turned into an important socialization area for children in Turkey, can affect children in many ways and children prefer digital games because they find it amusing, fun, enjoyable and exciting (Aslan et al, 2019). Thus, spending reasonable time on their phones.

All these were motives for the researchers to deliver a research study in North Cyprus students to find out the situation of Phubbing Behaviours and to suggest solutions for these. Quantitative research design was used for this study. The purpose of this study is to find differences between Turkish Speaking Students' Phubbing Behaviors according to education, job status, working status and gender.

\section{Materials}

After extensive literature survey, a questionnaire including three main parts, is designed. The first part includes demographic questions. The second and third parts include Generic Scale of Phubbing (GSP) and the Generic Scale of Being Phubbed (GSBP). GSP is used to assess phubbing behavior, and the GSBP is used to assess the experience of being phubbed. 


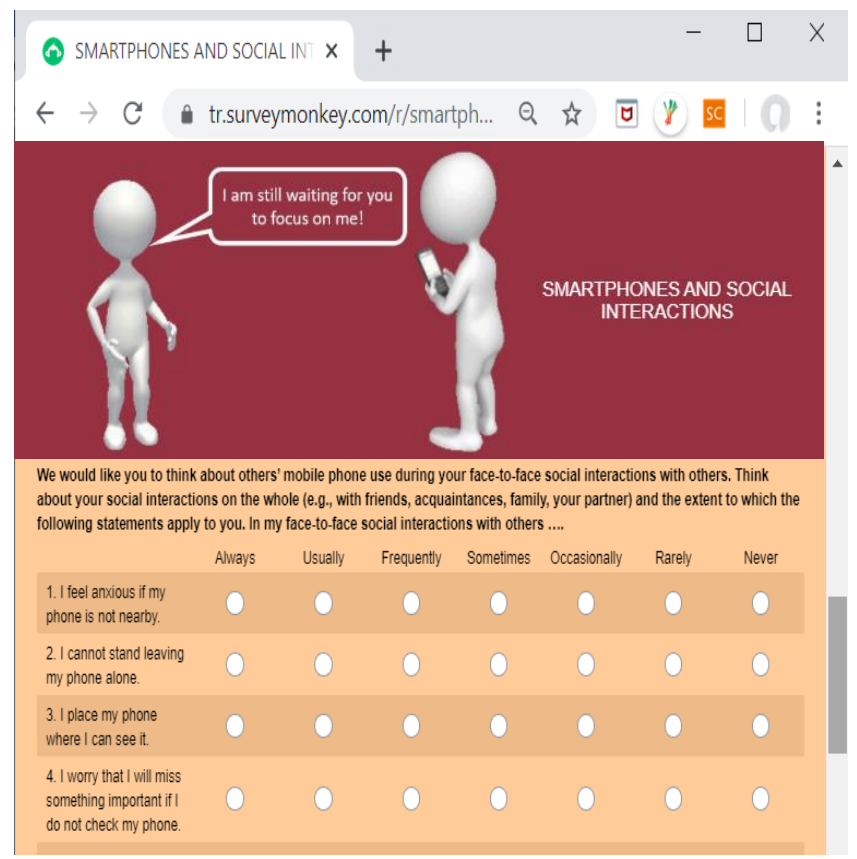

Figure 1. Survey monkey questionarrie

The four-factor 15-item GSP and the three-factor 22-item GSBP were developed and revealed good construct validities, criterion validities, convergent validities, discriminant validities, internal consistency reliabilities, and test-retest reliabilities (Chotpitayasunondh \& Douglas, 2018). The above-mentioned four factors of GSP scale includes; Nomophobia, Interpersonal Conflict, Self Isolation and Problem Acknowledgement; and the three factor GSBP scale includes; Perceived Norms, Feeling Ignored and Interpersonal Conflict (Chotpitayasunondh and Douglas, 2018).

The questionnaire written in Survey Monkey (see Figure 1) was initially distributed to experts for them to express their opinion. After making modifications according to their responses, a pilot study was carried out by distributing the questionnaires to small sample of fifty participants. After the making the final adjustments, and obtaining authorizations from related schools, the questionnaire was sent to over 500 Turkish speaking (Turkish and Turkish Cypriot) participants between October 2018 and February 2019.

\section{Population}

Over 500 online questionnaires were shared, via e-mail, WhatsApp and Messsenger Messages, after obtaining the authorization from schools. Participants who were below the age of 18 responded under their parent's or guardian's supervision. Turkish speaking 
Students who are overinteracting with mobile phones were preferred to be participants of this study, however their being involved/ not being involved is a volunteer status. Aim of this research was explained to them it would take only their 10 minutes and it is ensured that the data will not be used other than research purposes. Only 352 students filled in the online questionnaires during the 4 months.

Table 1. Demographic statistics of students

\begin{tabular}{|c|c|c|c|c|}
\hline & & Working & Not Working & Total \\
\hline \multirow{2}{*}{ Primary } & Female & 0 & 20 & \multirow{2}{*}{35} \\
\hline & Male & 0 & 15 & \\
\hline \multirow{2}{*}{ Secondary } & Female & 0 & 105 & \multirow{2}{*}{207} \\
\hline & Male & 0 & 102 & \\
\hline \multirow{2}{*}{ Undergraduate } & Female & 12 & 13 & \multirow{2}{*}{54} \\
\hline & Male & 20 & 9 & \\
\hline \multirow[b]{2}{*}{ Graduate } & Female & 15 & 3 & \multirow{2}{*}{56} \\
\hline & Male & 17 & 1 & \\
\hline
\end{tabular}

As seen in Table 1, students are divided into 4 categories; Primary, Secondary, Undergraduate and Graduate. Working status of students according to gender are also shown in Table 1. Primary and Secondary school students are in the Not Working category. Not Working category includes retired participants as well. The majority of our participants are from Secondary and Undergraduate educational categories.

\section{Statistics and Hypothesis}

IBM SPSS Statistics 25 and SurveyMonkey were used for statistical analysis. Descriptive statistics frequencies, percentages and Independent $t$-test results were used to analyze and to report the data collected from the questionnaire using Survey Monkey. Also graphics in this research are drawn in SurveyMonkey. These statistics were used according to the purpose of the study. Independent t-test statistics is used to test the null hypothesis in the study. Research hypothesis are

Ho $=$ There is no significant difference between female and male students' Phubbing Behaviors

$\mathrm{H}_{1}=$ There is significant difference between female and male students Phubbing Behaviors These hypothesis were tested in the $95 \%$ confidence interval. 


\section{Findings and Discussion}

The analysis and the results of the research are explained in the following tables and figures under the sections of: Phubber and Phubbee Statistics, According to Ages PhubberPhubbee and Working Status Statistics, The Generic Scale of Phubbing Statistics, The Generic Scale of Being Phubbed Statistics.

Phubber and Phubbee Statistics According to Ages

According to Figure 2, the tendency of phubbing behavior generally decreases as the age increases but above the age of 54 there is a significant increase in phubbing behavior.

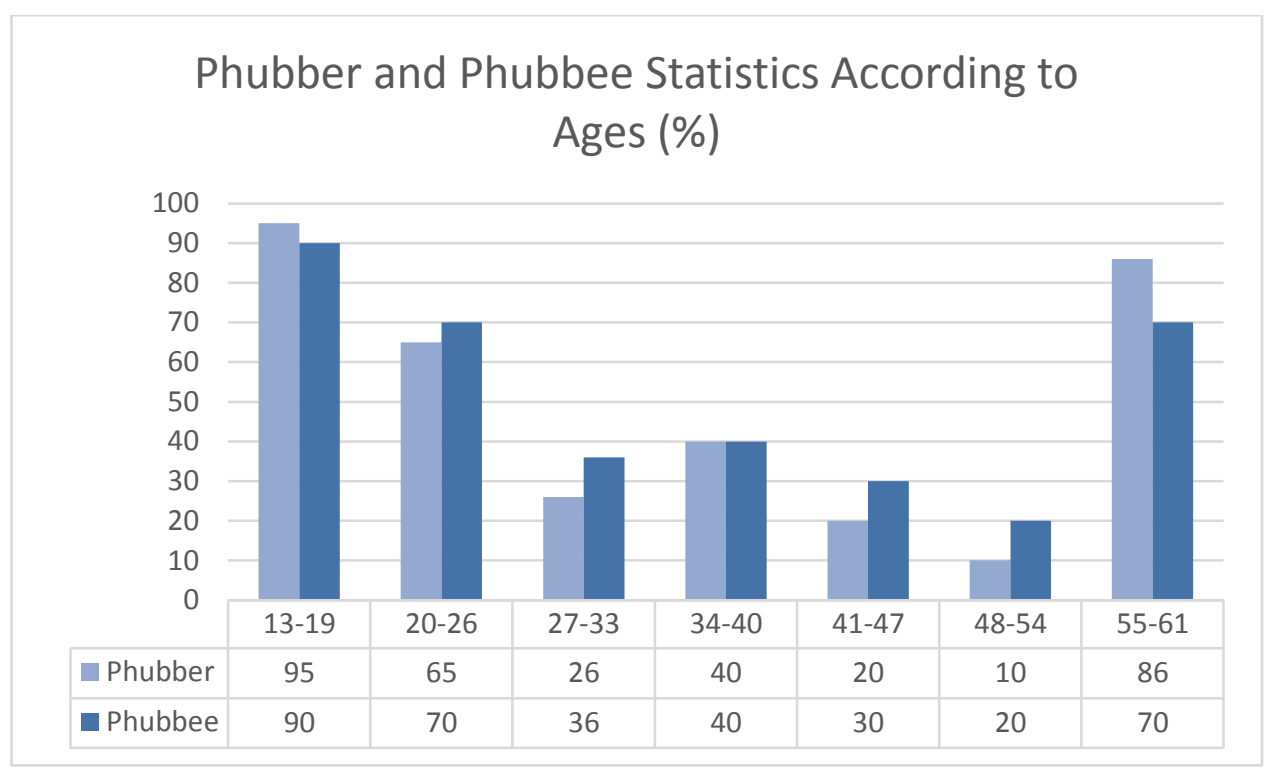

Figure 2. Tendency of phubbing behaviors among ages

Between the ages of 27-54 the perception of phubbing behaviour is observed to be below $40 \%$. Further research is needed to determine the reasons of the differences of phubbing behaviors among ages. On the other hand these show that all people regardless of their age are facing with Phubbing behaviors.

Phubbee-Phubber and Education Statistics

Phubbee-Phubber and Education Statistics are shown in Figure 3. Here, graduate school and primary school statistics are observed to be higher than Undergraduate and Secondary School statistics. 


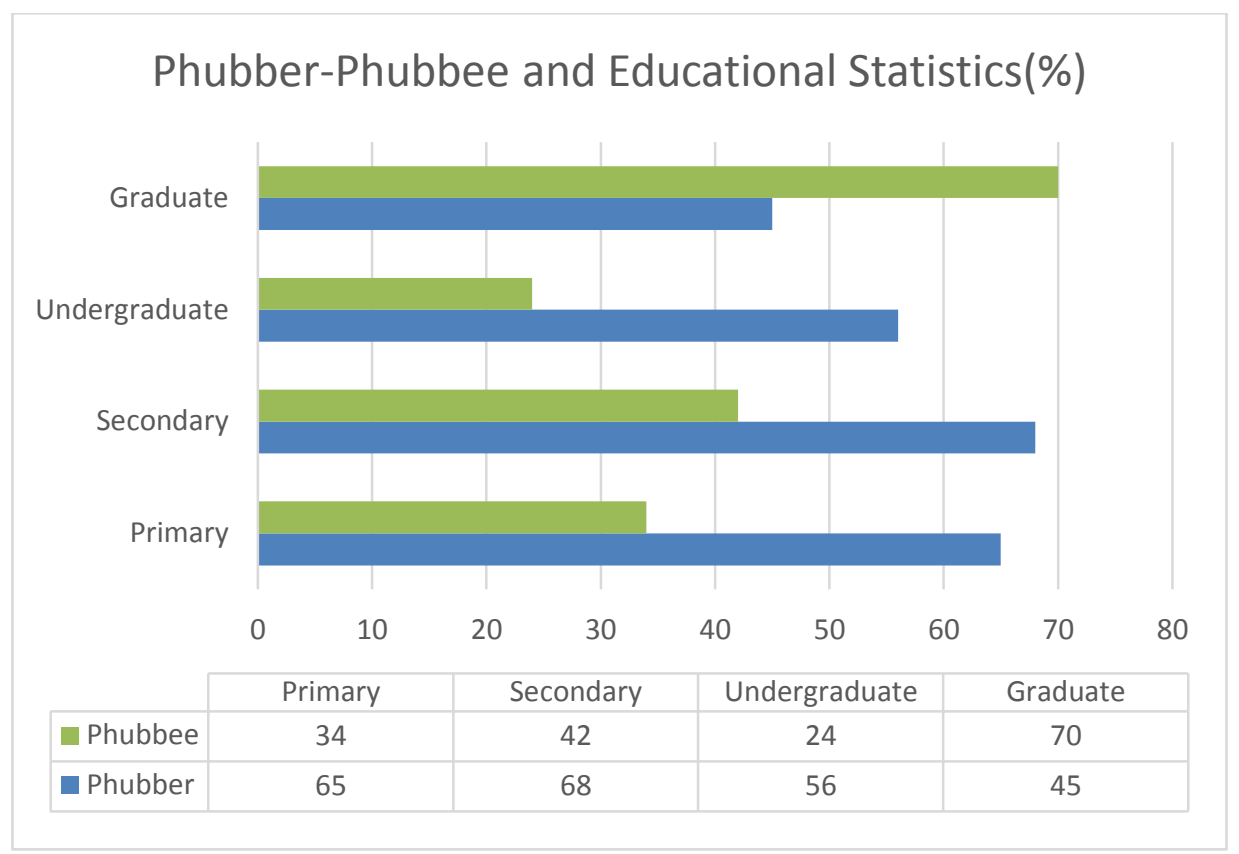

Figure 3. Education and phubber-phubbee statistics

On the other hand these show that all people regardless of their education level are facing with Phubbing behaviors.

\section{Phubber-Phubbee and Working Status Statistics}

Figure 4 illustrates Phubbee-Phubber and Working Status Statistics of students. In this section, working status is observed in 4 categories: Not Working, Working in Private Sector, Working in Public Sector and Retired.

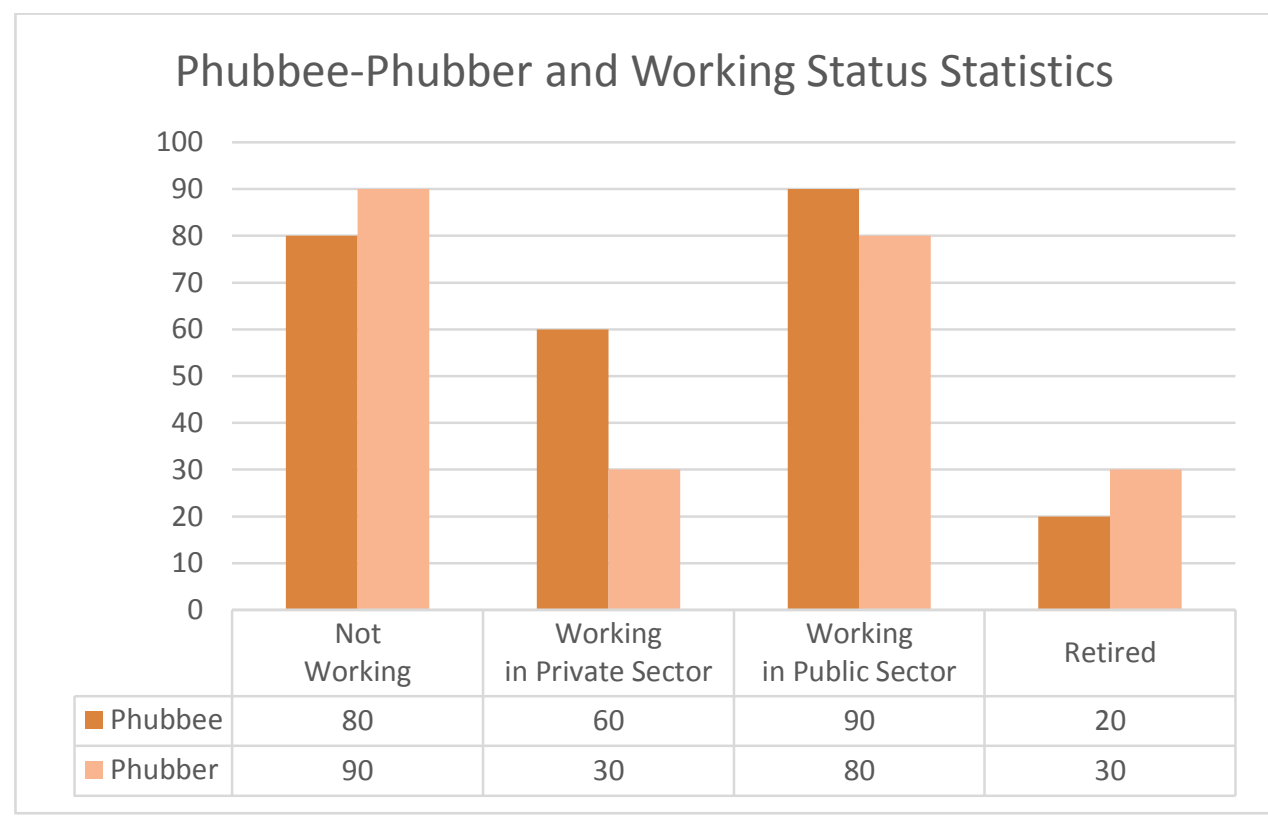

Figure 4. Phubber-phubbee and working status statistics 
It is observed that the working participants are phubbed more, when compared to the Not Working and Retired participants. Are working students using Smartphones more than retired students? Is this difference related with age? Further research is required to analyze the reasons of those behaviors. We have discussed Phubber and Phubbee age, working and educational statistics. We will explore independent $\mathrm{t}$-test results and mean in the following sections.

The Generic Scale of Phubbing Statistics

Four factors of Nomophobia, Interpersonal Conflict, Self Isolation and Problem Acknowledgement, the Generic Scale of Phubbing, were analyzed in IBM SPSS Statistics 25. Following descriptive statistics were obtained as a result of the analysis: Male and female participants showed different aspects of Nomophobia factor. Female participants (above $80 \%$ ) stated that they could not stand leaving their phone alone, whereas male participants (above 90\%) stated that they place their phones where they can see it. 
Table 2. The Generic scale of phubbing statistics

\begin{tabular}{|c|c|c|c|c|c|}
\hline \multirow{5}{*}{ Nomophobia } & \multirow{2}{*}{ The Generic Scale of Phubbing } & \multicolumn{2}{|c|}{ Male (\%) } & \multicolumn{2}{|c|}{ Female(\%) } \\
\hline & & $\begin{array}{l}\text { Turkish } \\
\text { Cypriot }\end{array}$ & Turkish & $\begin{array}{l}\text { Turkish } \\
\text { Cypriot }\end{array}$ & $\begin{array}{l}\text { Turki } \\
\text { sh }\end{array}$ \\
\hline & $\begin{array}{l}\text { 1. I feel anxious if my phone is not } \\
\text { nearby. }\end{array}$ & 80 & 66 & 80 & 78 \\
\hline & 2. I cannot stand leaving my phone alone. & 60 & 50 & 90 & 80 \\
\hline & 3. I place my phone where I can see it. & 98 & 90 & 64 & 60 \\
\hline \multirow{5}{*}{$\begin{array}{l}\text { Interpersonal } \\
\text { Conflict }\end{array}$} & $\begin{array}{l}\text { 4. I worry that I will miss something } \\
\text { important if I do not check my phone. }\end{array}$ & 50 & 60 & 60 & 80 \\
\hline & $\begin{array}{l}\text { 5. I have conflicts with others because } \\
\text { I am using my phone. }\end{array}$ & 60 & 64 & 30 & 36 \\
\hline & $\begin{array}{l}\text { 6. People tell me that I interact with } \\
\text { my phone too much. }\end{array}$ & 90 & 80 & 56 & 40 \\
\hline & $\begin{array}{l}\text { 7. I get irritated if others ask me } \\
\text { to get off my phone and talk to them. }\end{array}$ & 98 & 88 & 66 & 64 \\
\hline & $\begin{array}{l}\text { 8. I use my phone even though I know } \\
\text { it irritates others. }\end{array}$ & 74 & 70 & 70 & 76 \\
\hline \multirow{4}{*}{$\begin{array}{l}\text { Self- } \\
\text { Isolation }\end{array}$} & $\begin{array}{l}\text { 9. I would rather pay attention to my } \\
\text { phone than talk to others. }\end{array}$ & 10 & 4 & 9 & 8 \\
\hline & $\begin{array}{l}\text { 10. I feel content when I am paying } \\
\text { attention to my phone instead of } \\
\text { others. }\end{array}$ & 14 & 10 & 10 & 7 \\
\hline & $\begin{array}{l}\text { 11. I feel good when I stop focusing on } \\
\text { others and pay attention to my } \\
\text { phone instead. }\end{array}$ & 16 & 14 & 12 & 10 \\
\hline & $\begin{array}{l}\text { 12. I get rid of stress by ignoring others } \\
\text { and paying attention to my phone } \\
\text { instead. }\end{array}$ & 70 & 76 & 94 & 96 \\
\hline \multirow{3}{*}{$\begin{array}{l}\text { Problem } \\
\text { Acknowledge } \\
\text { ment }\end{array}$} & $\begin{array}{l}\text { 13. I pay attention to my phone for } \\
\text { longer than I intend to do so. }\end{array}$ & 60 & 70 & 70 & 65 \\
\hline & 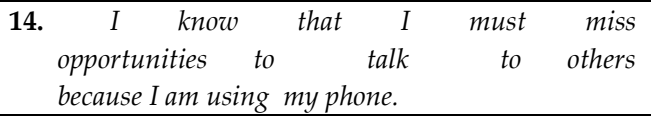 & 50 & 46 & 52 & 58 \\
\hline & $\begin{array}{l}\text { 15. I find myself thinking "just a few } \\
\text { more minutes" when I am using } \\
\text { my phone. }\end{array}$ & 70 & 60 & 88 & 98 \\
\hline
\end{tabular}

Regarding Interpersonal Conflict factor, male participants (above 80\%) stated that people tell them that they interact with their phones too much and they get irritated when others ask them to get off their phone to talk to them. Also, regarding Self-Isolation factor, all participants(female above $90 \%$, male above $70 \%$ ) stated that they get rid of their stress when paying attention to their phones. On the other hand, all participants (female less than $12 \%$, male less than $16 \%$ ) stated that they don't feel content when they are paying attention to their phone instead of others. 
Regarding Problem Acknowledgement factor, Female participants (above 88\%) admited that they find themselves thinking "just a few more minutes" when they are using their phones. Three factors of Perceived Norms, Feeling Ignored and Interpersonal Conflict According to the Generic Scale of Being Phubbed Statistics, were analyzed in IBM SPSS Statistics 25, and the following descriptive statistics were obtained as shown in Table 2. Also, regarding Perceived Norm factor, female participants (above 80\%) stated that they believe others have difficulty in putting their phones down and they are 'in their own world'.

Regarding Feeling Ignored factor, female participants (above 86\%) stated that others shift their attention to their phones instead of the person in front of them. Also, regarding Interpersonal Conflict factor, female participants (above 80\%) and male participants (above $56 \%)$ stated that they have conflicts with others because they are using their phones. On the other hand, less than $20 \%$ of the participants stated that they think others use their phones even though they know it irritates the person in front of them.

The Generic Scale of Being Phubbed Statistics

According to the Generic Scale of Being Phubbed Statistics, as shown in Table 3, all factors of Perceived Norms, Feeling Ignored and Interpersonal Conflict differences are observed in the following;

- Others seem worried that they will miss something important if they do not check their phones.

- Others seem like they have a difficult time putting their phones down.

- Others seem like they cannot stand leaving their phones alone.

- Others seem like they are "in their own worlds" using their phones.

- Others seem anxious if their phones are not nearby.

- Others seem like they get rid of boredom by paying attention to their phones instead of me.

- Others shift their attention from me to their phones

- I have conflicts with others because they are using their phones. 
Table 3. The generic scale of being phubbed statistics

\section{The Generic Scale of Being Phubbed (GSBP)}

Male (\%)

Female(\%)

\begin{tabular}{|c|c|c|c|c|}
\hline & $\begin{array}{l}\text { Turkish } \\
\text { Cypriot }\end{array}$ & Turkish & $\begin{array}{l}\text { Turkish } \\
\text { Cypriot }\end{array}$ & Turkish \\
\hline $\begin{array}{l}\text { 1. Others seem to check their phones } \\
\text { for messages and social media } \\
\text { updates. }\end{array}$ & 70 & 60 & 78 & 64 \\
\hline $\begin{array}{l}\text { 2. Others seem to be using their phones } \\
\text { to go online. }\end{array}$ & 90 & 90 & 90 & 90 \\
\hline $\begin{array}{l}\text { 3. Others place their phones where they } \\
\text { can see them. }\end{array}$ & 70 & 70 & 70 & 70 \\
\hline $\begin{array}{l}\text { 4. Others seem worried that they will } \\
\text { miss something important if they do } \\
\text { not check their phones. }\end{array}$ & 50 & 60 & 80 & 94 \\
\hline $\begin{array}{l}\text { 5. Others seem like they lose awareness } \\
\text { of their surroundings because of } \\
\text { their phone use. }\end{array}$ & 30 & 30 & 40 & 30 \\
\hline $\begin{array}{l}\text { 6. Others seem like they have a difficult } \\
\text { time putting their phones down. }\end{array}$ & 50 & 60 & 90 & 80 \\
\hline $\begin{array}{l}\text { 7. Others seem like they cannot stand } \\
\text { leaving their phones alone. }\end{array}$ & 78 & 70 & 90 & 94 \\
\hline $\begin{array}{l}\text { 8. Others seem like they are "in their } \\
\text { own worlds" using their phones. }\end{array}$ & 68 & 60 & 90 & 92 \\
\hline $\begin{array}{l}\text { 9. Others seem anxious if their phones } \\
\text { are not nearby. }\end{array}$ & 60 & 78 & 90 & 96 \\
\hline $\begin{array}{l}\text { 10. Others pay attention to their } \\
\text { phones rather than talking to me. }\end{array}$ & 30 & 30 & 30 & 30 \\
\hline $\begin{array}{l}\text { 11. Others would rather pay attention } \\
\text { to their phones than talk to me. }\end{array}$ & 70 & 82 & 80 & 80 \\
\hline $\begin{array}{l}\text { 12. Others seem like they get rid of } \\
\text { boredom by paying attention to } \\
\text { their phones instead of me. }\end{array}$ & 70 & 60 & 90 & 86 \\
\hline $\begin{array}{l}\text { 13. Others seem like they feel content } \\
\text { when they are paying attention to } \\
\text { their phones instead of me. }\end{array}$ & 70 & 60 & 70 & 70 \\
\hline $\begin{array}{l}\text { 14. Others pay attention to their } \\
\text { phones rather than focusing on me. }\end{array}$ & 40 & 30 & 40 & 40 \\
\hline $\begin{array}{l}\text { 15. Others seem like they get rid of } \\
\text { stress by aying attention to their } \\
\text { phones instead of me. }\end{array}$ & 40 & 42 & 40 & 44 \\
\hline $\begin{array}{l}\text { 16. Others seem like they feel good } \\
\text { when they stop focusing on me and } \\
\text { pay attention to their phones } \\
\text { instead. }\end{array}$ & 34 & 34 & 30 & 30 \\
\hline
\end{tabular}




\begin{tabular}{|c|c|c|c|c|c|}
\hline & $\begin{array}{l}\text { 17. Others shift their attention from } \\
\text { me to their phones }\end{array}$ & 60 & 50 & 90 & 96 \\
\hline & $\begin{array}{l}\text { 18. I tell others that they interact } \\
\text { with their phones too much. }\end{array}$ & 30 & 20 & 30 & 30 \\
\hline & $\begin{array}{l}\text { 19. I have conflicts with others } \\
\text { because they are using their } \\
\text { phones. }\end{array}$ & 60 & 56 & 80 & 90 \\
\hline $\begin{array}{l}\text { Interpersonal } \\
\text { conflict }\end{array}$ & $\begin{array}{l}\text { 20. I find myself thinking "I've had } \\
\text { enough" when others are using } \\
\text { their phones. }\end{array}$ & 30 & 26 & 30 & 28 \\
\hline & $\begin{array}{l}\text { 21. Others use their phones even } \\
\text { though they know it irritates me. }\end{array}$ & 18 & 16 & 20 & 20 \\
\hline & $\begin{array}{l}\text { 22. Others seem like they get irritated } \\
\text { if I ask them to get off their } \\
\text { phones and talk to me. }\end{array}$ & 32 & 26 & 30 & 28 \\
\hline
\end{tabular}

According to the analysis the following results are obtained;

In the analysis of Phubbing,

There is a significant difference between Female Participants $(\mathrm{M}=3.94, \mathrm{SD}=1.73)$ and Male Participants (M=3.48, SD=1.78) who said "I find myself thinking "just a few more minutes" when I am using my phone." and this difference is statistically meaningful. This finding could imply that female paricipants acknowledge the problem of finding themselves using their phones longer than they intend to, when compared to male participants.

\section{Independent t-test Results between Male and Female}

The shaded items shown in Table 2 and Table 3 show the significant differences between male and female participants. The details of the analysis are shown in Table 4 . According to the Generic Scale of Phubbing Statistics, as shown in Table 2, all factors of Nomophobia, Interpersonal Conflict, Self Isolation and Problem Acknowledgement, differences are observed in the following;

- I cannot stand leaving my phone alone.

- I place my phone where I can see it.

- I have conflicts with others because I am using my phone.

- People tell me that I interact with my phone too much.

- I get irritated if others ask me to get off my phone and talk to them. 
- I get rid of stress by ignoring others and paying attention to my phone instead.

- I find myself thinking "just a few more minutes" when I am using my phone.

Table 4. Independent t-test results between male and female

\begin{tabular}{|c|c|c|c|c|c|c|}
\hline & \multicolumn{6}{|l|}{ Group Statistics } \\
\hline & & Gender & $\mathbf{N}$ & Mean & $\begin{array}{l}\text { Std. } \\
\text { Dev }\end{array}$ & $\begin{array}{l}\text { Std.Error } \\
\text { Mean }\end{array}$ \\
\hline \multirow{14}{*}{$\begin{array}{l}\dot{\bar{D}} \\
\frac{0}{2} \\
\frac{1}{2}\end{array}$} & \multirow[t]{2}{*}{ 2. I cannot stand leaving my phone alone. } & Female & 174 & 5.13 & 1.426 & 0.108 \\
\hline & & Male & 178 & 4.63 & 1.723 & 0.129 \\
\hline & \multirow[t]{2}{*}{ 3. I place my phone where I can see it. } & Female & 174 & 3.68 & 1.831 & 0.139 \\
\hline & & Male & 178 & 4.20 & 1.826 & 0.137 \\
\hline & \multirow{2}{*}{$\begin{array}{l}\text { 5. I have conflicts with others because I am } \\
\text { using my phone. }\end{array}$} & Female & 172 & 3.39 & 1.984 & 0.151 \\
\hline & & Male & 178 & 3.83 & 2.022 & 0.152 \\
\hline & \multirow{2}{*}{$\begin{array}{l}\text { 6. People tell me that I interact with my phone } \\
\text { too much. }\end{array}$} & Female & 173 & 2.28 & 1.587 & 0.121 \\
\hline & & Male & 178 & 3.34 & 2.055 & 0.154 \\
\hline & \multirow{2}{*}{$\begin{array}{l}\text { 7. I get irritated if others ask me to get off my } \\
\text { phone and talk to them. }\end{array}$} & Female & 172 & 2.13 & 1.686 & 0.129 \\
\hline & & Male & 177 & 2.66 & 2.020 & 0.152 \\
\hline & \multirow{2}{*}{$\begin{array}{l}\text { 12. I get rid of stress by ignoring others and } \\
\text { paying attention to my phone instead. }\end{array}$} & Female & 167 & 3.99 & 1.846 & 0.143 \\
\hline & & Male & 176 & 3.43 & 1.875 & 0.141 \\
\hline & \multirow{2}{*}{$\begin{array}{l}\text { 15. I find myself thinking "just a few more } \\
\text { minutes" when I am using my phone. }\end{array}$} & Female & 171 & 3.94 & 1.724 & 0.132 \\
\hline & & Male & 178 & 3.48 & 1.773 & 0.133 \\
\hline \multirow{16}{*}{ 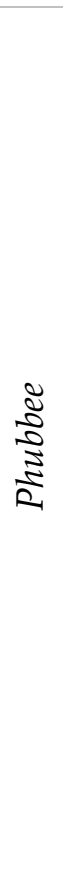 } & \multirow{2}{*}{$\begin{array}{l}\text { 4. Others seem worried that they will miss } \\
\text { something important if they do not check their } \\
\text { phones. }\end{array}$} & Female & 173 & 4.40 & 1.627 & 0.124 \\
\hline & & Male & 176 & 3.39 & 1.977 & 0.149 \\
\hline & \multirow{2}{*}{$\begin{array}{l}\text { 6. Others seem like they have a difficult time } \\
\text { putting their phones down. }\end{array}$} & Female & 171 & 4.66 & 1.580 & 0.121 \\
\hline & & Male & 173 & 4.11 & 1.906 & 0.145 \\
\hline & \multirow{2}{*}{$\begin{array}{l}\text { 7. Others seem like they cannot stand leaving } \\
\text { their phones alone. }\end{array}$} & Female & 172 & 4.52 & 1.674 & 0.128 \\
\hline & & Male & 176 & 3.85 & 1.902 & 0.143 \\
\hline & \multirow{2}{*}{$\begin{array}{l}\text { 8. Others seem like they are "in their own } \\
\text { worlds" using their phones. }\end{array}$} & Female & 173 & 4.47 & 1.457 & 0.111 \\
\hline & & Male & 177 & 4.11 & 1.869 & 0.141 \\
\hline & \multirow{2}{*}{$\begin{array}{l}\text { 9. Others seem anxious if their phones are not } \\
\text { nearby. }\end{array}$} & Female & 171 & 3.78 & 1.748 & 0.134 \\
\hline & & Male & 172 & 3.37 & 1.727 & 0.132 \\
\hline & \multirow{4}{*}{$\begin{array}{l}\text { 12. Others seem like they get rid of boredom by } \\
\text { paying attention to their phones instead of me. } \\
\text { 17. Others shift their attention from me to their } \\
\text { phones. }\end{array}$} & Female & 172 & 3.38 & 1.758 & 0.134 \\
\hline & & Male & 177 & 2.86 & 1.802 & 0.135 \\
\hline & & Female & 171 & 3.98 & 1.715 & 0.131 \\
\hline & & Male & 177 & 3.40 & 1.901 & 0.143 \\
\hline & \multirow{2}{*}{$\begin{array}{l}\text { 19. I have conflicts with others because they are } \\
\text { using their phones. }\end{array}$} & Female & 173 & 3.48 & 1.879 & 0.143 \\
\hline & & Male & 177 & 3.04 & 1.896 & 0.143 \\
\hline
\end{tabular}

There is a significant difference between Female Participants $(M=3.38, S D=1.76)$ and Male Participants ( $\mathrm{M}=2.86, \mathrm{SD}=1.80)$ who said "Others seem like they get rid of boredom by paying attention to their phones instead of $\mathrm{me}^{\prime \prime}$ and this difference is statistically meaningful. 
Also, there is a significant difference between Female Participants $(\mathrm{M}=3.98, \mathrm{SD}=1.72)$ and Male Participants $(\mathrm{M}=3.40, \mathrm{SD}=1.90)$ who said "Others shift their attention from me to their phones." and this difference is statistically meaningful. Similarly, there is a significant difference between Female Participants $(M=3.48, S D=1.88)$ and Male Participants $(M=3.04$, $\mathrm{SD}=1.90$ ) who said "I have conflicts with others because they are using their phones." and this difference is statistically meaningful.

Among Phubbee items, item 4 states that there is a significant difference between Female Participants $(M=4.40, S D=1.63)$ and Male Participants $(M=3.39, S D=1.98)$ who said "Others seem worried that they will miss something important if they do not check their phones." and this difference is statistically meaningful. Also, there is a significant difference between Female Participants $(\mathrm{M}=4.52, \mathrm{SD}=1.68)$ and Male Participants $(\mathrm{M}=4.11, \mathrm{SD}=1.87)$ who said "Others seem like they cannot stand leaving their phones alone." and this difference is statistically meaningful. Similarly, there is a significant difference between Female Participants $(\mathrm{M}=3.78, \mathrm{SD}=1.75)$ and Male Participants $(\mathrm{M}=3.37, \mathrm{SD}=1.72)$ who said "Others seem anxious if their phones are not nearby." and this difference is statistically meaningful.

It is found that for Phubber items $(2,3,4,5,6,7,12,15)$ and Phubbee items $(4,6,7,8$, $9,12,19,19)$ in the Scale is no significant difference between female and male students Phubbing Behaviors $(\mathrm{p}<0.05)$ and $\mathrm{H} 0$ is rejected in favor of $\mathrm{H} 1$. What is more, in total of two scales Phubbing Beavior scores showed significant difference between female and male students. Hence $\mathrm{H} 0$ rejected in favour of $\mathrm{H} 1$ for this research study.

There is a significant difference between Female Participants $(M=5.13, S D=1.43)$ and Male Participants ( $\mathrm{M}=4.63, \mathrm{SD}=1.72)$ who said "I cannot stand leaving my phone alone." and this difference is statistically meaningful.

In the analysis of Being Phubbed (Phubbee)

There is a significant difference between Female Participants $(\mathrm{M}=3.68, \mathrm{SD}=1.83)$ and Male Participants $(\mathrm{M}=4.20, \mathrm{SD}=1.83)$ who said "I place my phone where I can see it." and this difference is statistically meaningful. Also, there is a significant difference between Female Participants $(\mathrm{M}=3.39, \mathrm{SD}=1.98)$ and Male Participants $(\mathrm{M}=3.83, \mathrm{SD}=2.02)$ who said "I have conflicts with others because I am using my phone." and this difference is statistically meaningful. 
There is a significant difference between Female Participants $(\mathrm{M}=2.28, \mathrm{SD}=1.58)$ and Male Participants $(\mathrm{M}=3.34, \mathrm{SD}=2.06)$ who said "People tell me that I interact with my phone too much." and this difference is statistically meaningful. In addition to these, there is a significant difference between Female Participants $(M=2.13, S D=1.69)$ and Male Participants $(\mathrm{M}=2.66, \mathrm{SD}=2.02)$ who said "I get irritated if others ask me to get off my phone and talk to them." and this difference is statistically meaningful. Also, there is a significant difference between Female Participants $(\mathrm{M}=3.39, \mathrm{SD}=1.85)$ and Male Participants $(\mathrm{M}=3.43, \mathrm{SD}=1.88)$ who said "I get rid of stress by ignoring others and paying attention to my phone instead." and this difference is statistically meaningful.

\section{Conclusion and Recommendation}

Responses of the participants in GSP and GSBP Scales regarding Self-Isolation and Feeling Ignored Factors, consistently show that the participants do not feel content when themselves or others pay attention to their phones instead of having interaction with eachother. Smartphone usage time is positively related with phubber and as it is also positively related with nomophobia, there could be trainings regarding effective and efficient usage of smartphones (Toker \& Tuncay, 2020). More multidisciplinary researches with mind and body research studies as mentioned by Aydın \& Bulut( 2012) are required. According to the result of the analysis, all participants seemed to get rid of their stress by interacting with their phones, though they do not mean to irritate others by focusing on their phones. Stress is an unavoidable part of our educational life as well as our social life and it is a fact that we have to learn how to cope with it (Tuncay, et. al, 2020).

According to the Generic Scale of Phubbing Statistics, as shown in Table 2, all factors of Nomophobia, Interpersonal Conflict, Self Isolation and Problem Acknowledgement, differences are observed in the following;

- I cannot stand leaving my phone alone.

- I place my phone where I can see it.

- I have conflicts with others because I am using my phone.

- People tell me that I interact with my phone too much.

- I get irritated if others ask me to get off my phone and talk to them. 
- I get rid of stress by ignoring others and paying attention to my phone instead.

- I find myself thinking "just a few more minutes" when I am using my phone. According to the Generic Scale of Being Phubbed Statistics, as shown in Table 3, all factors of Perceived Norms, Feeling Ignored and Interpersonal Conflict differences are observed in the following;

- Others seem worried that they will miss something important if they do not check their phones.

- Others seem like they have a difficult time putting their phones down.

- Others seem like they cannot stand leaving their phones alone.

- Others seem like they are "in their own worlds" using their phones.

- Others seem anxious if their phones are not nearby.

- Others seem like they get rid of boredom by paying attention to their phones instead of me.

- Others shift their attention from me to their phones

- I have conflicts with others because they are using their phones.

In order to provide new directions for further studies in this research area, it is suggested to deliver a multicultural and multidisciplinary study with a larger population of participants.

Acknowledgement

The data used in this study was confirmed by the researchers that it belongs to the years before 2020.

Authorship Contribution Statement

Burcu TOKER: Conceptualization, design of the work, literature search, data collection, data analysis, data interpretation, writing - review and editing.

Nazime TUNCAY: Conceptualization, design of the work, , literature search, data collection, data analysis, , data interpretation, writing - review and editing. 


\section{References}

Aydın, Ü., \& Bulut, A. (2012). Bibliometric analysis of ADO journal of clinical sciences, Journal of Clinical Sciences, 6 (1), 1067-1075.

Aslan, A , Turgut, Y. , \& Karakuş Y. T. (2019). Game, environment and peer effect on children on the digital gaming habits in game arcades. Journal of Computer and Education Research, 7 (14) , 480-495.

Błachnio, A., \& Przepiorka, A. (2018). Be aware! If you start using facebook problematically you will feel lonely: phubbing, loneliness, self-esteem and facebook intrusion. A crosssectional study, Social Science Computer Review, 1-9.

Charlton, J. P., \& Danforth, I. D. W. (2010). Validating the distinction between computer addiction and engagement: Online game playing and personality, Behaviour $\mathcal{E}$ Information Technology, 29, 601-613.

Chasombat, P. (2015). Facebook effects on interpersonal communication: Study on Thai young adults, Journal of Public and Private Management, 22, 45-70.

Chotpitayasunondh, V., \& Douglas, K. M. (2016). How "phubbing" becomes the norm: The antecedents and consequences of snubbing via smartphone, Computers in Human Behavior, 63, 9-18.

Chotpitayasunondh, V., \& Douglas, K. M. (2018). The effects of "phubbing" on social interaction, Journal of Applied Social Psychology, 304-316.

David, M. E., \& Roberts, J. A. (2017). Phubbed and alone: Phone snubbing, social exclusion, and attachment to social media. Journal of the Association for Consumer Research, 2, 155163.

Erzen, E, Odaci,H. \& Yeniceri, İ. (2019), Phubbing: which personality traits? are prone to phubbing. Social Science Computer Review, 1-14

Fanga, J., Wang, X.,Wenc,Z., \& Zhoua , J. (2020). Fear of missing out and problematic social media use as mediators between emotional support from social media and phubbing behavior. Addictive Behaviors ,107 (2020), 1-7.

Göksu, İ., \& Bolat, Y. (2020). Teknoloji kullanımı türkiye'de öğrencilerin akademik başarılarını etkiliyor mu? bir meta-analiz çalışması. Ĕ̆itim Teknolojisi Kuram ve Uygulama , 10 (1) , 138-176.

Hassanzadeh, R., \& Rezaei, A. (2011). Effect of sex, course and age on SMS addiction in students. Middle-East Journal of Scientific Research, 10, 619-625.

Kircaburun, K., \& Griffiths, M. D. (2018). Instagram addiction and the Big Five of personality: The mediating role of self-liking. Journal of Behavioral Addictions, 7, 1-13.

Marshall, T. C., Lefringhausen, K., \& Ferenczi, N. (2015). The big five, self-esteem, and narcissism as predictors of the topics people write about in Facebook status updates. Personality and Individual Differences, 85, 35-40.

Metsiritrakul, K., Puntavachirapan, N., Kobchaisawat, T., Leelhapantu, S., \& Chalidabhongse, T. H. (2016). UP2U: Program for raising awareness of phubbing problem with stimulating social interaction in public using augmented reality and computer vision. 2016 13th International joint conference on computer science and software engineering, JCSSE 2016. 
Ozer, O . (2020). Smartphone addiction and fear of missing out: does smartphone use matter for students' academic performance?. Journal of Computer and Education Research (JCER), 8 (15), 344-355.

Pendergrass, W. S., \& Town, C. (2017). Phubbing: Communication in the attention economy. Paper presented at the Conference on Information Systems Applied Research, Austin, USA.

Roberts, J. A., \& David, M. E. (2016). My life has become a major distraction from my cell phone: Partner phubbing and relationship satisfaction among romantic partners. Computers in Human Behavior, 54,134-141.

Scheier, M. F., Carver, C. S., \& Bridges, M. W. (1994). Distinguishing optimism from neuroticism (and trait anxiety, self-mastery, and self-esteem): A reevaluation of the life orientation test. Journal of Personality and Social Psychology, 67, 1063-1078.

Shi, M., Liu, L., Yang, Y. L., \& Wang, L. (2015). The mediating role of self-esteem in the relationship between big five personality traits and depressive symptoms among Chinese undergraduate medical students. Personality and Individual Differences, 83, 55-59.

Sleem, W. F., \& El-Sayed, N. M. (2011). The effect of job conscientiousness on job performance. Nature and Science, 9, 1-7.

Stokes, J. P. (1985). The relation of social network and individual differences in loneliness. Journal of Personality and Social Psychology, 48, 981-991.

Tao, R., Huang, X., Wang, J., Zhang, H., Zhang, Y., \& Li, M. (2010). Proposed diagnostic criteria for internet addiction. Addiction, 105, 556-564.

Tuncay,N. (2016). Game preferences of 3 generations from the eye of students'. Journal of Computer and Education Research(JCER) , 4 (8) , 154-178.

Tuncay, N., Müdüroğlu,R., \& Bulut, A. (2020). Educational stress, social stress and gender differences among university students, Journal of Educational and Instructional Studies in the World,10 (2), 37-46.

Toker, B., \& Tuncay, N. (2020). Stress is an unavoidable part of our educational life as well as our social life and it is a fact that we have to learn how to cope with it. Journal of Educational and Instructional Studies in the World,10 (2), 19-27.

Ugur, N. G., \& Koc, T. (2015). Time for digital detox: Misuse of mobile technology and phubbing. Procedia Social and Behavioral Sciences, 195, 1022-1031.

Wang, X., Xie, X., Wang, Y., Wang, P., \& Lei, L. (2017). Partner phubbing and depression among married Chinese adults: The roles of relationship satisfaction and relationship length. Personality and Individual Differences, 110, 12-17.

Weinstein, A., \& Lejoyeux, M. (2010). Internet addiction or excessive internet use. The American Journal of Drug and Alcohol Abuse, 36, 277-283.

Wood, R. T. A. (2008). Problems with the oncept of video game "Addiction": Some case study examples. International Journal of Mental Health and Addiction, 6, 169-178.

Yakınc1, Z., Gürbüz, P., \& Yetiş, G. (2018). Internet usage habits and internet usage in educational studies of vocational school students. Journal of Computer and Education Research (JCER) , 6 (11) , 33-46.

Copyright $(\mathrm{C}$ JCER

JCER's Publication Ethics and Publication Malpractice Statement are based, in large part, on the guidelines and standards developed by the Committee on Publication Ethics (COPE). This article is available under Creative Commons CC-BY 4.0 license (https://creativecommons.org/licenses/by/4.0/) 